\title{
SHATTERING MYTHS: THE CURIOUS HISTORY OF THE BULGARIAN LAW OF OBLIGATIONS ${ }^{1}$
}

The history of private law is intimately tied to the political history of a nation. ${ }^{2}$ Common private law may symbolize unity and freedom. ${ }^{3}$ Often, when building a new State, a key priority, after enacting a constitution, is to enact a civil code. ${ }^{4}$ Reforms in private law may denote political changes and transitions within established States, too. In France, for instance, the Code Civil put an end to the excesses of the judges and curtailed corruption. ${ }^{5}$ Countries, which change political regimes, usually alter their civil codes to reflect the new political values. ${ }^{6}$

In this light, it is not surprising that in many European countries, the history of private law is well documented and well researched. ${ }^{7}$ That is why, when writing

${ }^{1}$ A version of this paper was presented at the $7^{\text {th }}$ Annual Conference on Comparative Law dedicated to the 'Evolution of Law' hosted by the SWPS University of Social Sciences and Humanities in Warsaw in 2017; The paper draws on research I undertook for my doctoral thesis. See R. Vassileva, Change of Economic Circumstances in Bulgarian and English Law. What Lessons for the Harmonization of Contract Law in the European Union?, Doctoral Thesis, University College London 2016.

${ }^{2}$ Hesselink observes that civil codes are always 'the result of political urge.' See M. Hesselink, The Politics of a European Civil Code, "European Legal Journal” 2004, Vol. 10, pp. 675, 684.

${ }^{3}$ Ibidem.

${ }^{4}$ For example, Italian unification was marked by the adoption of a constitution in 1861 and, subsequently, the first Italian Codice Civile of 1865. For a historical account, see M. Collier, Italian Unification: 1820-1871, Oxford 2003.

${ }^{5}$ It has been noted that French codification finally freed citizens 'from the despotic and unaccountable discretion exercised by judges under the old system,' M. Ascheri, Turning Point in the Civil-Law Tradition: From lus Commune to Code Napoléon, "Tulane Law Review" 1996, Vol. 70, pp. 1041, 1043.

${ }^{6}$ The evolution of the Russian/Soviet civil codes is particularly revealing. See A. Ostroukh, Russian Society and its Civil Codes: A Long Way to Civilian Civil Law, "Journal of Civil Law Studies" 2013, Vol. 6, p. 373.

${ }^{7}$ For instance, there is ample literature dedicated to the history of the French Code Civil. See A. Levasseur, Code Napoléon or Code Portalis?, "Tulane Law Review” 1969, Vol. 43, p. 762, J. Gordley, Myths of the French Civil Code, "The American Journal of Comparative Law" 1994, Vol. 42, p. 459; F. Ewald, Naissance du Code civil: la raison du législateur, Paris 2004, J. Visick, The Intellectual Influences on the Code Civil, "UCL Jurisprudence Review" 2009, Vol. 15, p. 198. 
my $\mathrm{PhD}$ in comparative private law, ${ }^{8} \mathrm{I}$ was puzzled by the mystery surrounding the Bulgarian Law of Obligations and Contracts (LOC) - the piece of legislation which governs the law of obligations in Bulgaria. ${ }^{9}$ While it was enacted in 1950, shortly after Bulgaria became a communist State, and it is still in force following cosmetic changes in the early $1990 \mathrm{~s},{ }^{10}$ almost nothing is known about its authors and its source of inspiration.

Through archival and comparative research, however, I believe I discovered its 'dark' secret - the document is heavily based on the Italian Codice Civile of 1942. Yet, why would a jurisdiction supposedly building a communist legal system post-1944 seek inspiration in the civil code of a jurisdiction with a rival ideology (Fascism) - Italy? The answer to this question raises concern about the superficial labeling of legal systems by the traditional taxonomies of comparative law. It also reveals the intricacies and peculiar patterns of legal change in Bulgaria, including the hidden mechanisms of resistance of radical legal change. ${ }^{11}$ Furthermore, it shows that comparative law could be a powerful tool in shattering myths in legal history.

\section{CONVENIENTH MYTHS}

Bulgarian textbooks seem to put forward convenient myths about the origin and history of the current LOC. One of the leading authorities in the law of obligations claims that the LOC is an original Bulgarian normative act created in accordance to the classical solutions of the continental (French-German) tradition'. ${ }^{12}$ In turn, one of the leading authorities in legal history argues that the LOC is based on 'the principles of socialist law and planned economy'. ${ }^{13}$

${ }^{8}$ As I was working on a comparison between English and Bulgarian law, I felt compelled to attribute Bulgarian law to a legal family when phrasing my research question. However, I had ample reasons to believe that the traditional Bulgarian narrative about the history of Bulgarian law was an example of propaganda, as explained below.

${ }^{9}$ Note that Bulgaria never had a civil code. Bulgarian legislators have always opted for a piecemeal approach - enacting laws and codes governing the various branches of law.

${ }^{10}$ The reform was carried out in 1993 and 1996. It allegedly restored the dualism of Bulgarian private law because a Law on Commerce was enacted, too. However, in practice, the latter is underdeveloped, so even commercial transactions are largely governed by the LOC.

${ }^{11}$ Mitchell contends that understanding how and why legal change takes place is fundamental for the academic study of law. He also emphasizes that it is important to go beyond traditional evidence to adequately understand the process of change and its implications, P. Mitchell, Patterns of Legal Change, "Current Legal Problems" 2012, Vol. 65, pp. 177-201.

${ }_{12}$ A. Kalaidjiev, The Law of Obligations: General Part, Sibi 2010, p. 26.

${ }^{13}$ D. Tokushev, History of the New Bulgarian State and Law 1878-1944, Sibi 2008, p. 182. 
These assertions always struck me as unconvincing, or at least, as half-truths. Firstly, the 1950 LOC was drafted and passed shortly after communism's arrival and there was insufficient time to create original Bulgarian solutions. Secondly, if the LOC contains 'classical continental solutions,' it is strange that the wording of its provisions neither resembles provisions of the French Code Civil nor of the German Bürgerliches Gesetzbuch. Thirdly, on a pan-communist scale, ideological socialist law was developed much after LOC's enactment. The first Soviet Civil Code was enacted in 1922, but it was primarily based on German, Swiss, and French law. Subsequent Soviet codes were substantially more ideologized, but they were passed after the LOC..$^{14}$ Also, when one compares the 1922 Soviet code with the LOC, there is little resemblance - they have similar structures, but the content is different and the LOC is noticeably longer. Essentially, while the LOC referred to certain socialist principles like the State economic plan and socialist coexistence, its authors did not follow any available socialist model.

Most of all, however, I refused to believe that Bulgaria's rich and complex legal tradition as well as its propensity to borrow foreign legal principles and to rely on comparative law as a vehicle of legal development could disappear immediately after communism was established. To clarify, the modern history of Bulgarian law can roughly be divided into three periods - re-establishment and development of the Bulgarian State after the Liberation from the Ottoman Empire (1878-1944), communism (1944-1989), and democracy (post-1989). Despite the major challenges it presented, the first period seems relatively well documented. The first Bulgarian constitution was adopted in 1879. Laws regulating the various branches of law were progressively enacted. ${ }^{15}$ The composition of the working groups and their sources of inspiration are known.

For historic reasons beyond the scope of this paper, ${ }^{16}$ the first Bulgarians with university degrees all studied abroad - the first jurists were no exception. ${ }^{17}$ As a result, there was ample comparative dialogue at the drafting stage of these various pieces of legislation. For instance, the first Bulgarian LOC of 1892 was

${ }^{14}$ The second Soviet Civil Code was enacted in 1964. On the Soviet codes' history and ideology, see A. Ostroukh, Russian Society..., pp. 388-390; Poland also enacted a new civil code in 1964 , but adopted a more 'Western' approach, which is why it was only necessary to amend it after communism ended. On the code's philosophy, see A. Rudzinski, New Communist Civil Codes of Czechoslovakia and Poland: A General Appraisal, "Indiana Law Journal" 1964, Vol. 41, p. 33; Hungary enacted a communist civil code in 1959.

${ }^{15}$ Law on Acquisition of Uninhabited Land (1880), Laws on the Court System (1880 and 1883), Law on Inheritance (1890), Law on Obligations and Contracts (1892), Law on Commerce (1897), etc.; For the most important legal initiatives, see D. Tokushev, History of the New Bulgarian State...

${ }^{16}$ As mentioned above, Bulgaria was under Ottoman rule, which was oppressive, until 1878. The first Bulgarian university - Sofia University - where students could study in Bulgarian was founded in 1888. Its Law Faculty opened doors only in 1892.

${ }^{17}$ Traditional destinations included France, Germany, Austria-Hungary, Switzerland, Romania, Russia, etc. 
developed by three experts who had degrees from Russia and Germany. ${ }^{18}$ The document, nonetheless, copied verbatim provisions on contracts and obligations of the Codice Civile of 1865. It borrowed Titles IV to XXI of Book III with the exception of Titles V and VIII which regulated marriage contracts and longterm leases. ${ }^{19}$

The name of the Law - Law on Obligations and Contracts - came from the name of Title IV of the Codice Civile. Some provisions, however, were copied from Código Civil, particularly the ones on contracts of insurance..$^{20}$ Both the Italian and the Spanish code of that time largely replicated the French Code Civil. The Bulgarian committee justified their choice by indicating that the laws of Italy and France contain everything that theory and practice have deemed most just and rational in resolving personal and property disputes. ${ }^{21}$ It is also interesting that the committee did not choose to replicate the provisions of the Code Civil directly, but worked with Italian and Spanish versions - it has been suggested that the small changes that Italian and Spanish lawmakers made when replicating the Code Civil were significant. ${ }^{22}$

Moreover, it is helpful to note that the first Bulgarian law professors were comparativists by nurture. As noted above, they all earned their education abroad - some of them felt at home in several jurisdictions. This, in turn, explains their research interests and expertise. To illustrate, one of the first tenured professors at the Law Faculty - Mihail Popoviliev - had earned his $\mathrm{PhD}$ at the Sorbonne. His thesis ${ }^{23}$ studies an institute related to the inheritance of gifts, but what is striking is that he examines not only Roman law and French law prior to codification, but also the equivalents of this institute in twenty additional jurisdictions. The work of Yosif Fadenhecht, ${ }^{24}$ the author of the first Bulgarian textbook on civil law, is also revealing. In his monograph A Comparative Study on the Law of Obligations, ${ }^{25}$ for example, he compares the provisions of the 1933 Polish Code of Obligations with the laws of Bulgaria, France, Italy, Germany, Austria, and Switzerland. Lyuben Dikov, another leading authority in civil and commercial law prior to communism, had defended

${ }^{18}$ D. Tokushev, History of the New Bulgarian State..., p. 173.

${ }^{19}$ I. Apostolov, The Law of Obligations: General Part, Sofia 1947, p. 15.

${ }^{20}$ Ibidem.

${ }^{21}$ D. Tokushev, History of the New Bulgarian State..., p. 177.

${ }^{22}$ I. Apostolov, The Law of Obligations..., p. 16.

${ }^{23}$ See $D u$ rapport à succession des Libéralités, en droit civil français et européen et au point de vue du droit international privé, Paris 1897.

${ }^{24} \mathrm{He}$ had earned his law degree and defended a thesis at the University of Leipzig. See Y. Fadenhecht, Das Selbstvertheidigungsrecht des Rechtsbesitzers gegen den Sachbesitzer: mit einem Excurs über das Selbstvertheidigungsrecht des Sachbesitzers, Leipzig 1897.

${ }^{25}$ Sofia 1936. 
his $\mathrm{PhD}$ at the University of Göttingen ${ }^{26}$ and published extensively abroad about the challenges in contract law at the time. ${ }^{27}$

Overall, I was under the impression that a key part of the puzzle was missing. Who wrote the LOC? What source did they draw on? Why is the history of the LOC blurred in mystery?

\section{LOOKING FOR ANSWERS}

The first step in my quest for answers was a visit to the archives of the Bulgarian Parliament. Ironically, examining the verbatim report of the sitting of 3 November 1950, at which the LOC was enacted, only raised further questions. Notably, from the report it is visible that the law was voted on unanimously without any discussion. The sitting lasted 5 hours and 23 minutes and only involved a general overview of the law by the Parliament's secretary and ideological speeches by the Minister of Justice and two Members of Parliament. The presentation of the law discloses that it was inspired by the Soviet Civil Code of 1922, Poland's Draft of a Bill on the General Part of Civil Law (1947) and Soviet doctrine. ${ }^{28}$ The speech of the Minister of Justice reveals that the law was drafted by the Ministry of Justice in the span of two years in collaboration with academics and the working class represented by factory workers organized by the Communist Party. ${ }^{29}$

The speeches provide ample illustration of communist propaganda: the origin of any positive development was traditionally attributed to the Party and the masses. However, it is unlikely that factory workers without high school education could participate in the drafting of a sophisticated instrument like the LOC, or speak fluent Russian to understand Soviet philosophy and the Soviet Civil Code. Furthermore, as noted above, there is little resemblance between the Soviet code and the LOC. The general part of Polish law could not serve as the basis of the law of obligations either. It was obvious to me that LOC's authors drew inspiration from an undisclosed source.

The second step in my quest for answers was to contact established Bulgarian scholars in the hope of learning more about LOC's origin. In 2013 I met with Pro-

${ }^{26}$ Das Institut des Strohmannes (die vorgeschobene Person) im bürgerlichen Rechte, Göttingen 1922.

${ }^{27}$ Il Diritto civile dell'avvenire, "Rivista internazionale di filosofia del diritto" 1931, Vol. 11, pp. 153-180; Norma giuridica e volontà privata, "Rivista internazionale di filosofia del diritto" 1934, Vol. 14, pp. 681-706; L'évolution de la notion de contrat, (in:) Etudes de droit civil à la mémoire de Henri Capitant, Dalloz 1939, pp. 201-218; Die Abänderung von Verträgen den Richter, (in:) Hedemann-Festschrift, Jena 1938.

${ }^{28}$ Stenographical Diary of the Plenary Sitting on 3 November 1950.

${ }^{29}$ Ibidem. 
fessor Sarafov from Sofia University who had been struggling with this question for years. ${ }^{30} \mathrm{He}$ told me that it was probable that the LOC was written by leading Bulgarian scholars whose names were not revealed because it would have been shameful for the Party to admit that communist law was written by capitalist scholars. He suspects Apostolov, Vassilev, and Kozhuharov as they wrote treatises on the law of obligations shortly prior and after LOC's enactment. ${ }^{31}$ Sarafov emphasized that it was likely that the LOC was inspired by the Codice Civile of 1942 - a fact that could not be disclosed because it would have been discreditable for the Party to admit that the communist LOC is partly based on the law of a Fascist country. Indeed, developing a new Codice Civile was one of Mussolini's goals after he rose to power - as explained below, following relatively minor amendments, it is still in force today. ${ }^{32}$

Sarafov further stressed that while during communism research on LOC's origin and influences was avoided for these 'shameful' reasons, current research on the topic is missing because it is generally accepted as a statement of fact that the LOC is an original Bulgarian legal text. Moreover, Italian is not a common foreign language for contemporary Bulgarian lawyers and research would be challenging.

Following the interview, I decided it was indispensable to delve into the Codice Civile of 1942 all the more that my research also showed that Apostolov was fluent in Italian ${ }^{33}$ - a fact which made a connection between the 1950 LOC and the 1942 Codice Civile probable because the drafting committee could have had access to the original text. Also, one of the most influential professors in the period before communism, Lyuben Dikov, had written an article explaining why the Codice Civile was the greatest achievement of codification. ${ }^{34}$

\section{THE 'DARK' SECRET}

My analysis shows that the LOC bears a striking resemblance to Book IV and partially Book II of the Codice Civile of 1942, which is still in force fol-

${ }^{30}$ Interview with Pavel Sarafov, Professor of Law, Law Faculty, Sofia University (Sofia, Bulgaria, 12 November 2013).

${ }^{31}$ I. Apostolov, The Law of Obligations...; L. Vassilev, Civil Law: General Part, Sofia 1951; A. Kozhuharov, The Law of Obligations, Sofia 1954; L. Vassilev, The Law of Obligations, Sofia 1954.

${ }^{32}$ Even prior to Mussolini's rule scholars were considering the need to implement new legislation. There was even a French-Italian project for a new code of obligations. For an account of the project and its merits, see S. G. Vesey-FitzGerald, The Franco-Italian Draft Code of Obligations, 1927, "Journal of Comparative Legislation and International Law" 1934, Vol. 14, p. 1.

${ }^{33}$ In his younger years he was teaching Italian at the Italian Lyceum in Sofia.

${ }^{34}$ L. Dikov, The New Italian Civil Code, "Annuaire de l'Université de Sofia" 1942, Vol. 27, p. 57. 
lowing amendments. Numerous provisions of the LOC resemble closely provisions in the Codice Civile. Many articles were copied almost verbatim. ${ }^{35}$ LOC's drafters, nonetheless, changed the order of articles to follow the structure of the 1922 Soviet Civil Code. Other provisions borrowed from the Codice Civile were slightly modified to suit communist ideology - compare, for instance, article 266, paragraph 2 of the $\mathrm{LOC}^{36}$ with article 1664 of the Codice Civile. ${ }^{37}$ The main difference is that the Bulgarian provision does not stipulate a threshold of change as under communism, the economy is planned and prices are fixed by the government. It should be noted that this is one of the most peculiar and characteristic articles of the Italian code - the Codice Civile is one of the first European civil codes to contain an explicit provision on economic impossibility. ${ }^{38}$

Yet, how can this paradox be explained - why would a country building the foundation of its 'socialist' law of obligations seek inspiration in a country supporting a rival ideology? One can only make conjectures regarding why the authors of the LOC decided to use the Codice Civile as a model for the Bulgarian law of obligations because of years of censorship. As mentioned above, Bulgaria was the first socialist country out of the Soviet Union to modify its law of obligations to reflect communist values and it had no proper example to follow. In addition, as explained above, Bulgaria's legal tradition was open to borrowing and had developed a culture of exchange with many jurisdictions, including Italy - not only the first LOC of 1892 was based on the 1865 Codice Civile, but

${ }^{35}$ Article 94 (LOC): 'Arrangements which a priori rule out or reduce the promisor's liability for deliberate actions or gross negligence shall be null and void.' This provision seems inspired by Article 1229, paragraph 1 of the current Codice Civile: 'Null is any agreement which excludes or limits the liability of the debtor for willful misconduct or gross negligence.'; Article 81, paragraph 1 (LOC): 'A promisor shall not be liable if the impossibility to perform an obligation is due to a reason for which he cannot be found to be at fault.' Compare this provision with Article 1218 (Codice Civile): 'The promisor who does not perform exactly his due obligation owes compensation for damages if he does not prove that his default or delay is due to an impossibility of performance which cannot be attributed to him.'

36 'If in the course of the performance of the contract the duly determined prices of materials or labor change, the compensation shall be adjusted accordingly, even where it was agreed upon as a total sum.'

37 'If, by reason of unforeseeable circumstances have occurred increases or decreases in the cost of materials or labor, such as to cause an increase or decrease greater than one-tenth of the total agreed price, any contractor may request a review of the same price. The review may be granted only for the difference that exceeds the tenth...'

${ }^{38}$ While in modern times German judges were the first in Europe to relieve parties from extremely burdensome performance following supervening events, the concept was codified in the Bürgerliches Gesetzbuch as its Section 313 in 2001. See J. Dawson, Effects of Inflation on Private Contracts: Germany, 1914-1924, "Michigan Law Review” 1934, Vol. 33, pp. 171-238. See also A. Janssen, R. Schultze, Legal Cultures and Legal Transplants in Germany, "European Review of Private Law" 2011, Vol. 2, pp. 225, 232. 
Bulgarian and Italian scholars were in constant dialogue at the beginning of the $20^{\text {th }}$ century. ${ }^{39}$

Furthermore, examining Bulgarian scholarly writing prior to communism reveals that prominent authors, notably Lyuben Dikov mentioned above, were fascinated with organic social theory which they viewed as a viable alternative to liberal individualism which underlay the French Code Civil and the 1865 Codice Civile whose rules on obligations Bulgaria had initially borrowed in its 1892 LOC..$^{40}$ Dikov published numerous articles in Bulgaria, Italy, France, and Germany on how organic theory has redefined contract and the purpose of contract law. ${ }^{41}$ As noted above, he also dedicated an article to the merits of the 1942 Codice Civile, which he praised as the most successful example of codification. ${ }^{42}$ Considering this, it seems important to emphasize that while the Communist Party did not reveal the names of the authors of the LOC, it seems likely that the piece of legislation was drafted by adherents of Dikov who were well aware of his work and may have shared his values - Apostolov, Vassilev, and Kozhuharov, who Professor Sarafov mentioned, were all his students and/or colleagues. ${ }^{43}$

In that light, it is worth mentioning that the 1942 Codice Civile was heavily influenced by organic social theory, and in particular by Italian corporatism. ${ }^{44}$ Mattei and di Robilant, for example, have underlined the 'social orientation' and 'collective dimension' of Italian doctrine and case law which carried 'the seeds of corporate ideology that played a major role in the genesis of the code' ${ }^{45}$ Moreover, Filippo Vassalli, one of the fathers of the Codice Civile, has emphasized its organic dimension:

The regime of obligations and individual rights is constantly adapted to the needs of the national economy either by regulatory action of the corporate

${ }^{39}$ Tzeko Torbov translated many works by the jurist-philosopher del Vecchio who also came to Bulgaria to give lectures. Furthermore, del Vecchio taught Venelin Ganev's theories (a Bulgarian authority) in his classes in Italy, N. Nenovski, The Political Philosophy of Giorgio del Vecchio, "Yuridicheski svyat" 1999, Vol. 1, p. 226.

${ }^{40}$ For an analytical summary of his views, see R. Vassileva, Contract Law and the Social Contract: Rethinking Law Reform in the Field of Contract Law from the Perspective of Social Contract Theory, "Pravni život" 2016, Vol. III, issue 11, Year LXV, pp. 267-286.

${ }^{41}$ See footnote 27.

${ }^{42}$ L. Dikov, The New Italian..., p. 57.

${ }^{43}$ The Bulgarian academic legal community was relatively small as the country had one Law Faculty - the one at Sofia University.

${ }^{44}$ On the development and current state of corporatism in Italy, see M. Salvati, The Long History of Corporatism in Italy: A Question of Culture or Economics?, "Contemporary European History" 2006, Vol. 15, p. 223; See also C. Spinsante, Il corporativismo fascista: Il dibattito italiano sulla riforma corporativa dello Stato durante gli anni Venti e la sua recezione da parte del conservatorismo tedesco nella Repubblica di Weimar, Doctoral Thesis, University of Macerata 2012.

${ }^{45}$ U. Mattei, A. di Robilant, Les longs adieux. La codification italienne et le code Napoléon dans le déclin du positivisme étatiste, "Revue internationale de droit comparé" 2004, Vol. 4, pp. $847,851$. 
order expressly referred to in the [civil] code, or by a number of criteria, such as the protection of production...the duty to act honestly and in good faith, the duty of corporate solidarity, which...tend to place the rights of individuals in an organic link with the economic life and morality of the nation. ${ }^{46}$

The organic influence has translated into numerous provisions providing for greater State regulation and judicial intervention in agreements. It has been emphasized that the first version of the 1942 Codice Civile reflected the strong accent on the productivity of the enterprise, economic solidarity and the superior interest of the nation, which was a feature of the Italian Fascist notion of contract. ${ }^{47}$ These features of the Italian civil code must have appealed to the authors of the LOC. Their main challenge was to transform the 'rightist' organic dimension into a 'leftist' one, which must not have been too difficult having in mind that a 'socialist' economy has similar priorities - emphasis on productivity, social solidarity, and the primacy of State interests over private ones.

In principle, the Codice Civile itself had relatively few provisions which directly referred to ideology. That is why it was relatively easy to 'defascize' it after the fall of Mussolini in $1943 .^{48}$ Merryman, one of the Western scholars who has researched the history of the Codice Civile, has stressed:

The more substantial part of the governmental program of revision was not Fascist in origin. It consisted of a desire to reform the private law in the interests of increased national production, more adequate distribution of wealth, and greater social justice, all to be achieved through expansion of the role of the state. This was not a purely Italian tendency... ${ }^{49}$

In addition, he has noted:

In fact, the 1942 Code is not a Fascist document. Once a certain amount of superstructure was cleared away, a solid juristic accomplishment remained, built on the foundations laid in the nineteenth century codes and incorporating some of the more prominent trends in the thought of the twentieth century. ${ }^{50}$

In other words, all the Bulgarian drafters had to do was to rethink the few ideological provisions in the Codice Civile from the perspective of Marxian terminology and keep the rest intact.

When one compares some of the most ideologically charged articles from the original version of the 1942 Codice Civile and the original 1950 LOC, one sees differences in ideological terminology but not in function. For example,

${ }^{46}$ F. Vassalli, Studi Giuridici. Volume III, Giuffrè 1960, p. 615.

${ }^{47}$ P. G. Monateri, A. Somma, The Fascist Theory of Contract: A Comparative and Historical Inquiry into the Darker Side of Contract Law, "Cardozo Electronic Law Bulletin" 2009, p. 1.

${ }^{48}$ It was 'defascized' by the same working group which drafted it.

49 J. H. Merryman, The Italian Style II: Law, "Stanford Law Review" 1966, Vol. 18, pp. 396, 412.

${ }^{50}$ Ibidem, p. 413. 
Article 1322 of the original 1942 Codice Civile stipulated: 'Parties are free to determine the content of the contract within the limits imposed by law and by corporate rules. Parties may enter agreements which are non-standard as long as they aim at realizing an interest that deserves protection by the law.' Article 9 of the communist LOC stated: 'Parties may freely determine the content of their agreement as long as it does not contravene the law, the people's economic plan, and the rules of socialist coexistence.' Furthermore, Article 1175 of the original 1942 Codice Civile stipulated: 'The promisor and the promisee should behave according to the rules of decency in relation to the principles of corporate solidarity.' Article 63 of the communist Law on Obligations and Contracts stated: 'The promisee and the promisor should abide in their relations by the rules of socialist coexistence, socialist good faith, and the State economic plan.' In both documents, societal norms considerably restricted private will and subjected the content and performance of the contract to moral and economic judicial review. Moreover, in both instruments there was no reference to universal human morality, but to the specific moral rules and economic objectives embraced by the State.

\section{BEYOND THE DARKNESS}

One can draw both positive and negative conclusions based on the discussion above, which can inform further work in comparative law, especially comparisons between East and West European jurisdictions:

\subsection{THE POLITICAL TAINT OF LAW}

The fascinating discovery that a communist country sought inspiration in a Fascist model raises concern about the 'political taint of law. ${ }^{51}$ For years, Bulgarian law has been labeled somewhat unjustly for political reasons, which have relatively little to do with its substance.

For instance, the theory of legal families, primarily associated ${ }^{52}$ with the work of René David ${ }^{53}$ and Zweigert and Kötz, ${ }^{54}$ continues to inform comparative

${ }^{51}$ Credit should be given to Professor Paul Mitchell from UCL who used this term at my PhD defense and encouraged me to explore the question further.

${ }^{52}$ The idea of legal families existed before David's and Zweigert and Kötz's works were published. Yet the books of these authors have come to be regarded as a staple of reference. For a historical overview of the development of the theory, see M. Pargendler, The Rise and Decline of Legal Families, "The American Journal of Comparative Law" 2012, Vol. 60, pp. 1043-1074.

${ }^{53}$ See R. David, Traité élémentaire de droit civile comparé, Paris 1950.

${ }^{54}$ See K. Zweigert, H. Kötz, Einführung in die Rechtsvergleichung auf dem Gebiete des Privatrechts, Mohr 1969. 
research $^{55}$ in the law of obligations as well as the teaching of comparative law. ${ }^{56}$ Despite ample differences between the criteria they used to classify legal systems, ${ }^{57}$ David, on the one hand, and Zweigert and Kötz, on the other, recognized the existence of a socialist legal family. ${ }^{58}$ While subsequently there was debate over whether these jurisdictions indeed constituted a separate family ${ }^{59}$ or were merely a sub-branch of the civil tradition as they shared common features, ${ }^{60}$ one could note a propensity to group these jurisdictions together and to focus on the presumed similarities between them - same ideology, lack of separation between public and private law, etc.

Certainly, the similarities between communist legal systems cannot be denied, but there seem to be important substantive differences, which have been ignored because of the political label. Bulgaria, for instance, is one of the few former-communist countries that did not carry out a major reform of its law of obligations post-1989. The main reason for this is that Bulgaria's LOC had very little ideological language in it, which necessitated only cosmetic changes. As mentioned above, after the fall of Mussolini, it was relatively easy to 'defascize' the Codice Civile, which is still in force, for the same reasons. Hence, from a Bulgarian perspective, it seems ironic that Zweigert and Kötz pronounced socialist

${ }^{55}$ Comparative methodological literature traditionally refers to the theory of legal families. See, for instance, M. Graziadei, Comparative Law as the Study of Transplants and Receptions, (in:) R. Zimmermann, M. Reimann (eds.), The Oxford Handbook of Comparative Law, Oxford 2006, pp. 442-474; See also E. Örücü, A General View of "Legal Families" and of "Mixing Systems", (in:) E. Örücü, D. Nelken (eds.), Comparative Law: A Handbook, Hart 2007, pp. 169-189.

${ }^{56}$ Traditionally, comparative law classes in Western Europe focus on the so-called 'parent' jurisdictions - England, France, and Germany.

${ }^{57}$ For David the main criterion was ideology while Zweigert and Kötz took four additional factors into consideration - history, the characteristic mode of thought, distinctive institutions, and legal sources. See K. Zweigert, H. Kötz, Introduction to Comparative Law, Clarendon 1998, p. 68.

${ }^{58}$ David divided legal systems into Western, Socialist, Islamic, Hindu and Chinese. He divided Western law into French and Anglo-American; Zweigert and Kötz divided legal systems into Romanistic, Germanic, Common law, Nordic, Socialist, Far Eastern, and Hindu.

${ }^{59}$ Merryman recognized socialist law as one of the three major legal traditions together with the civil law and the common law. See J. H. Merryman, The Civil Law Tradition, Stanford 1969; In their treatise on comparative law, Gambaro and Sacco dedicate a separate chapter to Eastern Europe and the Socialist Model, (in:) A. Gambaro, R. Sacco, Sistemi Giuridici Comparati, UTET 1996, pp. 411-459.

${ }^{60}$ Quigley admitted that 'socialist law contains features that distinguish it from the legal systems of other countries of the civil law family,' but those features have not removed it from the civil law tradition, J. Quigley, Socialist Law and the Civil Tradition, "The American Journal of Comparative Law" 1989, Vol. 37, pp. 781, 808; Ajani asserts: 'During the Socialist era, despite declamations on the "originality of socialist law," Western models were borrowed, even if a careful scholarship disguised them, or judges were unaware of their origin,' G. Ajani, By Chance and Prestige: Legal Transplants in Russia and Eastern Europe, "The American Journal of Comparative Law" 1998, Vol. 43, p. 93, 94. 
law dead in the late 1990s as the same LOC is still in force and pretty much alive following relatively cosmetic changes. ${ }^{61}$

Modern taxonomies of comparative law seem equally biased. Ugo Mattei has argued that there are three main patterns of law - the rule of professional law, the rule of political law, and the rule of traditional law. ${ }^{62}$ The first pattern encompasses the Western legal tradition, the second - the law of development and transition, and the third - law with an Oriental view. Mattei includes 'the majority of the ex-Socialist legal family, with the possible exception of those countries (perhaps Poland, Hungary, and the Czech Republic) where Socialist law had to face a highly sophisticated civilian heritage and whose impact has been therefore less deep' in the second group. ${ }^{63}$

It is certainly commendable that Mattei goes beyond purely formalistic requirements and focuses on the process behind lawmaking and adjudication instead to justify his taxonomy. Nonetheless, Mattei's scheme seems to blur the differences between East European jurisdictions and, to a certain extent, to exaggerate the differences between East European jurisdictions and the Western tradition. In his scheme, Bulgaria and Italy would fall into two different groups, which is misleading, considering the substantive similarities between Bulgarian and Italian law referred to above. It should be noted that he put forward this classification in 1997 after the fall of communism and after Bulgaria had removed the ideological language from the LOC. Notwithstanding that the same principles of obligations were and probably still are applied differently because of the legal cultural context and heritage, it seems that Mattei exaggerated the role of the 'political' to merely fit a label.

Moreover, it should be remembered that communism took over East European countries for different reasons and was not homogeneous. In other words, the 'political' permeated lawmaking and adjudication to a different degree in the various socialist States during communism, which, in turn, explains the diverging roles of the 'political' after the end of communism, too.

\subsection{THE LEGAL SCHOLAR AS AN AGENT OF CHANGE OR RESISTANCE}

Scholars seem to forget that legal change is often induced or prevented by people like them. Legislation is usually drafted by very small working groups

${ }^{61}$ The preface to the 1998 edition of their famous book states: 'The socialist legal family is dead and buried, and although it will take a long time to erase the traces of more than forty years of total subjection to political ideology, it seemed right to discard the chapters on socialist law.' K. Zweigert, H. Kötz, Introduction to Comparative Law..., p. V.

${ }^{62}$ U. Mattei, Three Patterns of Law: Taxonomy and Change in the World's Legal Systems, "The American Journal of Comparative Law" 1997, Vol. 45, pp. 5-44.

${ }^{63}$ Ibidem, p. 30. 
composed of scholars or experts in a given field. ${ }^{64}$ Hence, it is inevitably informed by the personal views of those who contributed to it. The system of enacting legislation in communist Bulgaria is not much different from the current system. Bills are passed without much discussion and voted on by Members of Parliament who either have not read the Bill or do not have the expertise to evaluate its merits. They inform their opinion based on advice from their political party, the expert opinion of the competent parliamentary committee, etc. In other words, even today, the drafters have much leeway in promoting their ideas without too much scrutiny.

In Bulgaria, communism gave power to people without education who did not have the capacity to build the communist legislative framework by themselves. Inasmuch as they disliked the 'bourgeois,' they had to rely on former 'bourgeois' scholars to draft the Bills they wanted to implement. At the time the LOC was drafted, Bulgaria had few experts on obligations, so it seems logical to assume the Communist Party had to use their knowledge and abilities. Moreover, it seems reasonable to suspect that these experts could sell any myth to the Communist Party about their methodology and sources of inspiration just because the Party leadership did not have the sophistication to engage in fact-checking. Maybe that is why the 'trick' of promoting a law of obligations, which was based on Italian law, as law 'inspired from Soviet doctrine' worked.

If one digs deeper, one may even see a story of rebellion, a story of scholarly resistance or even continuity of Bulgaria's legal tradition. Professor Mattei, who I cited above, did not recognize Bulgaria as a country with a sophisticated civilian heritage, but I vehemently disagree with him. Following the Liberation from the Ottoman Empire in 1878, Bulgaria was in a unique position. It had to rebuild its State literally from 'scratch' very quickly ${ }^{65}$ but it had internationally qualified experts that established comparative dialogue as the staple for legislative drafting and scholarship. The solutions they put forward were research-informed 'patchworks' of what they deemed most pertinent. This particularity of Bulgaria's legal culture remained up to communism.

In other words, the scholars who wrote the 1950 LOC seem to have stuck to their beliefs and methods despite the political pressures they were most likely subjected to. As mentioned above, for various reasons, Bulgarian scholars were fond of the Italian legal culture in the period before communism, so they made sure to curate the provisions of the Codice Civile they considered most relevant in the circumstances. Furthermore, they prevented Bulgaria from having a highly ideologized LOC, which probably they were capable of drafting if they were truly

${ }^{64}$ As mentioned above, the first Bulgarian LOC was drafted by a group of three experts; The working groups on important European Union initiatives are also rather small: the working group on European contract law had 17 members who were mostly scholars.

${ }^{65}$ This explains its piecemeal, hectic approach to legislating, which has remained to this day. 
committed. They managed to bow to the communist regime, and yet promote their own views of law reform at the end.

\subsection{THE POWER OF COMPARATIVE LAW}

Why do we compare? This is arguably one of the questions, which has disturbed the sleep of many comparative scholars. ${ }^{66}$ The motivation behind a given angle of comparison can be personal - the intellectual interests and curiosity of the author. It can also be very pragmatic - examining the legal solutions in foreign jurisdictions may provide insights for national law reform. Important harmonizing initiatives on an international scale have been inspired by comparative scholars, too. ${ }^{67}$

My query into the origin and influences of the Bulgarian law of obligations, however, demonstrates another key strength of comparative law - it could be a powerful tool for shattering myths in legal history. The discovery that the Bulgarian LOC is inspired from the Codice Civile is certainly surprising. Yet, more surprising is the fact that leading contemporary Bulgarian authorities fell victim to Bulgarian communist propaganda. A lie has gone almost unnoticed for nearly 70 years because of the lack of substantive comparative research.

In many ways this is unfortunate because, as explained above, Bulgaria had a vibrant comparative tradition prior to communism, which has faded away. Years of censorship, lack of funding, and the docile form of scholarship, which has been encouraged, ${ }^{68}$ may shed light on this development. My personal observation is that in the end communism managed to tame the critical spirit and curiosity of scholarship - much of modern Bulgarian doctrinal writing appears descriptive and lacks zeal. ${ }^{69}$

On a brighter note, it is never too late to shatter myths because, to paraphrase a famous quote by Michael Crichton from his novel Timeline, '[if] you [don't] know history, then you [don't] know anything. You [are] a leaf that [doesn't] know it [is] part of a tree. ${ }^{70}$ Carrying out further archival and comparative research is not only indispensable for the sake of historical accuracy, but also for the enrich-

\footnotetext{
${ }^{66}$ On the major debates regarding the discipline's name, scope, and methodology, see E. Örücü, Developing Comparative Law, (in:) E. Örücü, D. Nelken (eds.), Comparative Law: A Handbook, Hart 2007, pp. 43-65.

${ }^{67}$ For example, the project for the harmonization of contract law in the EU. See M. Hesselink, The Politics..., p. 685.

${ }^{68}$ In totalitarian societies, scholars have to bow to the regime and justify its policies rather than criticize them or exercise independent thinking.

${ }^{69}$ See my discussion in Chapter 2 of R. Vassileva, Change of Economic Circumstances...

${ }^{70}$ The original quote is: 'Professor Johnston often said that if you didn't know history, you didn't know anything. You were a leaf that didn't know it was part of a tree,' Michael Crichton, Timeline, Alfred Knopf 1999, p. 73.
} 
ment of our understanding of the stage Bulgaria is at and the problems it needs to solve in the future.

This is not merely a Bulgarian matter. These questions are relevant for all scholars interested in the patterns of legal change as well as those putting forward taxonomies of comparative law. Any label put on a legal system based on assumptions rather than substantive research is not justified: it simply propagates stereotypes, biases future research, and compromises the understanding of other legal cultures.

Ultimately, there is also a need for more international comparative dialogue. As an East European scholar with a West European educational background, I have always been stunned by the lack of 'Western' interest in the particularities of East European jurisdictions. ${ }^{71}$ Beyond prosaic reasons, such as linguistic difficulties or the timing, which are always a diplomatic excuse, ${ }^{72}$ one can see the ghost of superiority - East European jurisdictions are treated as students that should learn and take example from the West rather than jurisdictions which have their own path of historical development and experience, positive or negative, which can be valuable. It seems convenient to assume that they have nothing new or interesting to tell - yet another myth we need to shatter.

A more meaningful East-West comparative dialogue can open new venues for research and give new impetus to comparative law. It can tell us more about the limits of the discipline, too. For years, West European comparativists were looking forward to developing common principles of contract in the European Union. ${ }^{73}$ At one point, a European Civil Code was even envisaged..$^{74}$ Yet, it turns out that the Bulgarian and Italian principles of obligations have been harmonized since the 1950 s, which by itself may provide a fascinating case study about the differences in application of the very same rules because of the diverging legal cultural context. Such a study may also shed light on the (im)possibility of harmonization and the factors which play a role.

${ }^{71}$ The disinterest in East European systems is particularly visible in the debate concerning the harmonization of contract law in the European Union. Even publications aiming to identify the common principles of 'European' contract law ignore East European jurisdictions altogether. See S. Whittaker, R. Zimmermann (eds.), Good Faith in European Contract Law, Cambridge 2000; J. Cartwright, M. Hesselink (eds.), Precontractual Liability in European Private Law, Cambridge 2011.

${ }^{72}$ Many East European scholars speak foreign languages, so collaborations can easily be envisaged. Whereas during communism collaborations were not feasible, many East European countries are now members of the European Union, so the lack of substantive dialogue is difficult to excuse.

${ }^{73}$ For an overview of the initiative, see L. Miller, The Emergence of EU Contract Law: Exploring Europeanization, Oxford 2012.

${ }^{74}$ In 2010, the Commission published a green paper proposing seven options for future of the Draft Common Frame of Reference among which a regulation on a European Civil Code, a regulation on European Contract Law, a toolbox, etc.: COM(2010)348 final; Because of the negative response, the Draft Common Frame of Reference remained an academic undertaking. 


\section{CONCLUSION: KEEP SHATTERING MYTHS}

Contrary to the mainstream narrative, archival and comparative research demonstrates that Bulgaria's LOC, which was enacted during communism, is heavily based on the Italian Codice Civile of 1942. Exploring the reasons behind this legislative choice as well as the reasons why this 'dark' secret was buried for so long challenges the traditional taxonomies of comparative law, reveals the peculiar patterns of legal change, including the key role of the legal scholar in the process, and demonstrates the power of comparative law in shattering myths in legal history.

The lessons I drew left me with a bitter taste. It appears that sometimes we have to question the obvious because well-known facts may turn out to be mantras of lies. Surely, authorities have different incentives why they spread myths. For the authors of the LOC, the motivation may have been to spare themselves the anger of the Communist Party. For contemporary scholars spreading myths about the LOC, the reason may be their trust in prior authority, which made them victims of propaganda. While we may be sympathetic to both groups, we should not forget that as scholars we have a duty to question. Keep shattering myths!

\section{BIBLIOGRAPHY}

Ajani G., By Chance and Prestige: Legal Transplants in Russia and Eastern Europe, "The American Journal of Comparative Law" 1998, Vol. 43

Apostolov I., The Law of Obligations: General Part, Sofia 1947

Ascheri M., Turning Point in the Civil-Law Tradition: From lus Commune to Code Napoléon, "Tulane Law Review" 1996, Vol. 70

Cartwright J., Hesselink M. (eds.), Precontractual Liability in European Private Law, Cambridge 2011

Collier M., Italian Unification: 1820-1871, Heinemann 2003

Crichton M., Timeline, Alfred Knopf 1999

David R., Traité élémentaire de droit civile comparé, Paris 1950

Dawson J., Effects of Inflation on Private Contracts: Germany, 1914-1924, "Michigan Law Review" 1934, Vol. 33

Dikov L., Das Institut des Strohmannes (die vorgeschobene Person) im bürgerlichen Rechte, Göttingen 1922

Dikov L., Il Diritto civile dell'avvenire, "Rivista internazionale di filosofia del diritto" 1931, Vol. 11

Dikov L., Norma giuridica e volontà privata, "Rivista internazionale di filosofia del diritto" 1934, Vol. 14

Dikov L., L'évolution de la notion de contrat, (in:) Etudes de droit civil à la mémoire de Henri Capitant, Dalloz 1939

Dikov L., Die Abänderung von Verträgen den Richter, (in:) Hedemann-Festschrift, Jena 1938 
Dikov L., The New Italian Civil Code, “Annuaire de l'Université de Sofia” 1942, Vol. 37

Ewald F., Naissance du Code civil: la raison du législateur, Flammarion 2004

Fadenhecht Y., Das Selbstvertheidigungsrecht des Rechtsbesitzers gegen den Sachbesitzer: mit einem Excurs über das Selbstvertheidigungsrecht des Sachbesitzers, Leipzig 1897

Fadenhecht Y., A Comparative Study on the Law of Obligations, Sofia 1936

Gambaro A., Sacco R., Sistemi Giuridici Comparati, UTET 1996

Gordley J., Myths of the French Civil Code, "The American Journal of Comparative Law" 1994, Vol. 42

Graziadei M., Comparative Law as the Study of Transplants and Receptions, (in:) R. Zimmermann, M. Reimann (eds.), The Oxford Handbook of Comparative Law, Oxford 2006

Hesselink M., The Politics of a European Civil Code, "European Legal Journal” 2004, Vol. 10

Janssen A., Schultze R., Legal Cultures and Legal Transplants in Germany, "European Review of Private Law" 2011, Vol. 2

Kalaidjiev A., The Law of Obligations: General Part, Sibi 2010

Kozhuharov A., The Law of Obligations, Sofia 1954

Levasseur A., Code Napoléon or Code Portalis?, "Tulane Law Review” 1969, Vol. 43

Mattei U., Three Patterns of Law: Taxonomy and Change in the World's Legal Systems, "The American Journal of Comparative Law" 1997, Vol. 45

Mattei U., di Robilant A., Les longs adieux. La codification italienne et le code Napoléon dans le déclin du positivisme étatiste, "Revue internationale de droit comparé" 2004, Vol. 4

Merryman J. H., The Italian Style II: Law, "Stanford Law Review” 1966, Vol. 18

Merryman J. H., The Civil Law Tradition, Stanford 1969

Miller L., The Emergence of EU Contract Law: Exploring Europeanization, Oxford 2012

Mitchell P., Patterns of Legal Change, "Current Legal Problems" 2012, Vol. 65

Monateri P. G., Somma A., The Fascist Theory of Contract: A Comparative and Historical Inquiry into the Darker Side of Contract Law, "Cardozo Electronic Law Bulletin" 2009, Vol. 1

Nenovski N., The Political Philosophy of Giorgio del Vecchio, "Yuridicheski svyat" 1991, Vol. 1

Örücü E., A General View of "Legal Families" and of "Mixing Systems", (in:) E. Örücü, D. Nelken (eds.), Comparative Law: A Handbook, Hart 2007

Örücü E., Developing Comparative Law, (in:) E. Örücü, D. Nelken (eds.), Comparative Law: A Handbook, Hart 2007

Ostroukh A., Russian Society and its Civil Codes: A Long Way to Civilian Civil Law, "Journal of Civil Law Studies" 2013, Vol. 6

Pargendler M., The Rise and Decline of Legal Families, "The American Journal of Comparative Law" 2012, Vol. 60

Popoviliev M., Du rapport à succession des Libéralités, en droit civil français et européen et au point de vue du droit international privé, Paris 1897

Quigley J., Socialist Law and the Civil Tradition, "The American Journal of Comparative Law" 1989, Vol. 37 
Rudzinski A., New Communist Civil Codes of Czechoslovakia and Poland: A General Appraisal, "Indiana Law Journal" 1964, Vol. 41

Salvati M., The Long History of Corporatism in Italy: A Question of Culture or Economics?, "Contemporary European History" 2006, Vol. 15

Spinsante Ch., Il corporativismo fascista: Il dibattito italiano sulla riforma corporativa dello Stato durante gli anni Venti e la sua recezione da parte del conservatorismo tedesco nella Repubblica di Weimar, Doctoral Thesis, University of Macerata 2012

Tokushev D., History of the New Bulgarian State and Law 1878-1944, Sibi 2008

Vassalli F., Studi Giuridici. Volume III, Giuffrè 1960

Vassilev L., Civil Law: General Part, Sofia 1951

Vassilev L., The Law of Obligations, Sofia 1954

Vassileva R., Change of Economic Circumstances in Bulgarian and English Law. What Lessons for the Harmonization of Contract Law in the European Union?, Doctoral Thesis, University College London 2016

Vassileva R., Contract Law and the Social Contract: Rethinking Law Reform in the Field of Contract Law from the Perspective of Social Contract Theory, "Pravni život" 2016, Vol. III, issue 11, Year LXV

Vesey-FitzGerald S. G., The Franco-Italian Draft Code of Obligations, 1927, "Journal of Comparative Legislation and International Law" 1934, Vol. 14

Visick J., The Intellectual Influences on the Code Civil, "UCL Jurisprudence Review" 2009, Vol. 15

Whittaker S., Zimmermann R. (eds.), Good Faith in European Contract Law, Cambridge 2000

Zweigert K., Kötz H., Einführung in die Rechtsvergleichung auf dem Gebiete des Privatrechts, Mohr 1969

Zweigert K., Kötz H., Introduction to Comparative Law, Clarendon 1998

\section{Others}

Interview with Pavel Sarafov, Professor of Law, Law Faculty, Sofia University (Sofia, Bulgaria, 12 November 2013)

Stenographical Diary of the Plenary Sitting of the Bulgarian Parliament on 3 November 1950

\section{SHATTERING MYTHS: THE CURIOUS HISTORY OF THE BULGARIAN LAW OF OBLIGATIONS}

\section{Summary}

While Bulgarian scholars concur that Bulgaria's Law of Obligations and Contracts, which was enacted in 1950 and which is still in force today following cosmetic changes in the early 1990s, is an original Bulgarian legal text, archival and comparative research 
shows that it is heavily based on the Italian Codice Civile of 1942 . Why would a communist country seek inspiration in a country with a Fascist ideology? Exploring the reasons behind this legislative choice as well as the reasons why this 'dark' secret was buried for so long challenges traditional taxonomies of comparative law, reveals the peculiar patterns of legal change, including the key role of the legal scholar in the process, and demonstrates the power of comparative law in shattering myths in legal history.

\section{KEYWORDS}

Bulgarian Law of Obligations and Contracts, history of Bulgarian law, history of the Bulgarian law of obligations, influences of Bulgarian law, Italian Codice Civile, comparative legal history, patterns of legal change, myths in legal history, communist law of contract, Fascist law of contract

\section{SŁOWA KLUCZOWE}

Bułgarskie prawo o zobowiązaniach i umowach, historia prawa bułgarskiego, historia bułgarskiego prawa zobowiązań, wpływy na prawo bułgarskie, włoski Codice Civile, porównawcza historia prawa, uwarunkowania zmian prawa, mity w historii prawa, komunistyczne prawo umów, faszystowskie prawo umów 